\title{
Monopoly Game Of Aksara Jawa As Teaching Tool In Javanese Language Learning
}

\author{
Amalia Dyah Pratiwi, Sumilah \\ Elementary School Teacher of Education Department, Faculty of Education, Universitas Negeri Semarang \\ Corresponding email: amaliadpratiwi12@gmail.com
}

\begin{abstract}
This study was aimed at knowing the development, feasibility and effectiveness of a Javanese script-based monopoly game learning medium on Javanese Language subject as a very feasible learning medium and helpful to improve the cognitive learning achievement of the fourth grade students of Islam Al madina Semarang. This study employed to Research and Development $(R \& D)$ method. The population and samples of this study were the students of class IV C of Islamic Elementary School (SD) Al Madina Semarang chosen by using random sampling. The data collection technique used by the researchers were questionnaire, interview, documentation, observation and test. Meanwhile, the data analysis was done by using the tests of validity, reliability, normality, t-Test, and $\mathrm{N}$-gain. In the expert judgement phase, all experts agreed that the Javanese scriptbased monopoly game was very feasible to use as a learning medium with some revisions based on their feedbacks. Moreover, the feasibility percentages given by the experts were $98 \%$ from media expert, $97.8 \%$ from materials experts, and $94.3 \%$ from language expert. Further, this Javanese script-based monopoly game learning medium affected on the cognitive learning achievement of students proven by the different average scores of students understanding based on t test as many as 11.666 and average increase ( $N$-gain) of 0.78 with high criterion. In conclusion, the Javanese script-based monopoly game learning medium is effective to be used as a learning medium.
\end{abstract}

Keywords: Javanese Language; Javanese script-based monopoly game; Learning Achievement; Development

\section{Introduction}

Education plays important role in human life in order to transform the values such as religious, cultural, scientific, technological, and skill values in order to build the dignitious, knowledgeable, and well-characterized humankind. Under the Act of Republic of Indonesia (20/2003) on National Education System article 1 verse 1, education is conscious and systematic measures to create the learning atmosphere and learning process in order that the students actively develop their individual potentials to have the spiritual and religious power, self-control skill, personalities, intelligence, and good characters, as well as the skills required by himself, the people, nations, and state. The purposes of the education need to be achieved through learning improvement process comprising the teacher's role, the students' activeness and learning outcomes.

Curriculum for primary and secondary education must contain religious study, citizenship study, language learning, mathematics, natural science, social science, sports, vocational subjects, and local subjects. The description can be found in article 7 verse 1 of Act (20/2003) on National Education System. The Regulation of Minister of Education (22/2006) explains that local subjects are curricular activities adapted to local characteristics and potentials including local strengths the materials of which cannot be classified into the existing subjects. The contents/substances of local subjects are determined by the schools.

Javanese language is the local one spoken in Jawa Tengah (Central Java), Jawa Timur (EastJava), and Daerah Istimewa Yogyakarta (Special Region of Yogyakarta). Because Javanese is typical local language which also becomes culture in each region, Javanese is made local subject to primary school (SD), secondary school (SMP), and High school (SMA). Basic competencies in Javanese subject varies, from unggah-ungguh basa (spoken politeness), ukara tanduk (active voice), cangkrliman (riddles), to aksara jawa (Javanese character), they are all learnt to Javanese subject.

The problems of the poor learning outcome in Javanese language was found in SD Islam Al Madina Semarang. Based on the observation and the interviews with Mrs. Windyati, S.Pd. as the teacher of Javanese subject to grade IV C students of SD Islam Al Madina Semarang on December 14-19, 2017, I found that the children then found it hard to speak the good Javanese. I do not wonder that the children find it hard, even their own parents find it hard to teach them Javanese. While, as a native Javanese, knowing of Javanese language is a must. This thing happens to the students of SD Islam Al Madina Semarang. Because of their unability to speak the good Javanese, they then gradually do not like the Javanese subject. Based 
on the observation that I conducted, one of the lesson materials that they find difficult to learn is aksara Jawa (Javanese script).

Aksara Jawa becomes one of lesson materials the students are less able to master. The students seem to find it so difficult to identify the Javanese script that they do not want to open the book and learn Javanese reluctantly. Grade IV students should be able to identify each character well to learn Javanese script. In fact, however, the students still are confused when differentiating one character from another one. Usually, when doing Javanese exercise, they rely on the printed Javanese script pasted on the classroom wall. Only a few of them, however, can see the printed script clearly. Those who do not see clearly open their Pepak Basa Jawa (Complete Javanese) respectively. They also still often guess the answers to the questions in the Javanese exercises asked by the teacher. Thus the Javanese learning outcomes are still poor and not at best. The poor and not the best Javanese learning outcomes are shown in their average Javanese regular exercise score. Of 27 students, only $12(45 \%)$ meet KKM, and 15 others $(55 \%)$ did not meet KKM, and the determined KKM was 70 .

Based on the data above, I need tools to improve the students learning achievement and to develop their critical thinking skill, one of which is through the teaching tool. In additition to using the teaching during the learning, another method that I took to make the students happy with the learning is learning by playing. This argument is strengthened by Pitadjeng (2006:96) who stated, one of the learning methods that can improve the students' learning enthusiasm is learning by playing a game. Several studies state that learning by playing a game will improve the students' activeness. In line with the study conducted by Chung Hong Lin published in Educational Technology \& Society Journal Vol 16 No 2 in 2012 titled "Game-Based Remedial Instruction in Mastery Learning for Upper Primary School Students".

Another study that supported this issue is the one conducted by Purwanto, et.al., (Vol. 17 No. 1, April 2012) titled "Implementasi permainan Monopoli Fisika Sebagai Media Pembelajaran dalam Pembelajaran Kooperatif Tipe TGT untuk Meningkatkan Prestasi Belajar dan Mengetahui Profil Kemampuan Berpikir Kritis Siswa SMP" (Implementation of Monopoly Game as Teaching Tool in TGT-Type Cooperative Learning to Improve the Students'
Learning Achievement and to Find Out Profile of the Students' Critical Thinking Skill). The research shows that the students whose learning outcomes improve after applying the monopoly game to physics learning.

Another typical research was conducted by Maulia Syahbarina (Vol. 4 No. 3, in 2017) titled Pengembangan Media MONORAJA (Monopoli Aksara Jawa) untuk Siswa Sekolah Dasar (The Development of MONORAJA (Monopoli Aksara Jawa) to the Students in Primary Schools). This research is (Research and Development) that aims to develop a teaching tool, i.e. MONORAJA (Monopoli Aksara Jawa) in Javanese subject particularly Aksara Jawa lesson for grade 3 students.

Another study that supports this investigation is the one conducted by Solekhah (Vol. 09 No. 07, in 2015) titled Pengembangan Media Monopoli Tematik Pada Tema "Tempat Tinggalku" Untuk Siswa Kelas IV SD N Babarsari (Development of Thematic Monopoly on the Theme "My Living Place" for Grade IV Students of SD N Babarsari). The research shows that the assessment of the media assessor scored average 3.9 and is included into "feasible" category. The assessment conducted by lesson materials assessor scored average 4.8 and is included into "feasible" category. In the preliminary field testing I got score $85 \%$ and is included in "good" category for feasibility test. In the main field testing, it got score $93.7 \%$ and is included in "good" category for its feasibility. In the operational field testing I got score $97.5 \%$ and is included in "good" category for its feasibility. We can draw conclusion that thematic monopoly for thematic learning to grade IV students is effective.

The problem list in this research comprises (1) How is the Javanese Script Monopoly developed in Javanese learning in grade IV C students of SD Islam Al Madina Semarang? (2) How feasible is the Javanese Script Monopoly for Javanese learning in grade IV C students of SD Islam Al Madina Semarang? (3) How effective is the Javanese Script Monopoly for Javanese learning in grade IV C students of SD Islam Al Madina Semarang?

Based on the problems above, this investigation aims to develop the Javanese Script development design for the Javanese learning in grade IVC students of SD Islam Al Madina Semarang, to find the feasibility of Javanese Script Monopoly during the Javanese learning in grade IV C students of SD Islam Al Madina 
Semarang, to find the effectiveness of Javanese Script Monopoly during the Javanese learning in grade IV C students of SD Islam Al Madina Semarang.

\section{Research Methods}

The type of the research I conducted was Research and Development (R\&D). The research method that I took was Research and Development (R\&D) in Sugiyono (2015:409) model. Langkah-langkah model ini terdiri dari 9 langkah sebagai berikut: (1) Problem identification; (2) Information Collecting; (3) Designing Preliminary Form of Product; (4) Preliminary Field Testing; (5) Preliminary Product Revision; (6) Main Product Testing; (7) Main Product Revision; (8) Operational Product Testing .(9) Mass Production.

Variable for this research comprises design and component of Javanese script monopoly in Javanese learning particularly Javanese script lesson by applying monopoly containing Javanese script.

Population of this research is grade IV C students of SD Islam Al Madina Semarang. Sample for this investigation is IV C students of SD Islam Al Madina Semarang through random sampling method. Random sampling (non probability sampling) is saturation sampling when all members of population are used as samples (Sugiyono, 2013:122)

The data collection method that I took was observation to observe the students' activities, the test was used to assess the learning outcomes that reflects the effectiveness of monopoly containing Javanese script in the Javanese learning particularly Javanese script lesson. In addition, I also used questionnaires on teacher and students' needs to find the responses of the teacher and the students on monopoly game containing Javanese script as well as completed with documentation.

The data analysis method that I applied was product data analysis, to find the feasibility of the monopoly game containing Javanese script. The initial data analysis/ analysis requirement test, t-test was used to find the average difference of Javanese learning outcomes before and after the application of the monopoly game containing Javanese script. Gain test was used to find the improvement of the learning outcomes.

\section{Results And Discussion}

The results and discussion comprise model and design of monopoly game containing Javanese script, validation of the assessment conducted by the assessors, and effectiveness of monopoly game containing Javanese script.

\section{Design of Monopoly Game Containing Javanese Script}

Husna (2016:116) stated that monopoly was one of the most popular board games in the world. This game aims to take control of all the lands on the board through property purchase, rent, and exchange in the simplified economic system. Every player throws the dices in rotation to ease the his pawn, and when he stops on the land which is not owned by another player, he can buy the land at the written price. If the land has been bought by another player, he must pay the rent at the determined price.

The children will more easily get the lesson by assistance of the teaching tool in form of a game. This is strengthened by an investigation made by Nur Azizah (PGSD Vol.01:2012) titled Penerapan Media Monopoli Untuk Meningkatkan Hasil Belajar Siswa Pada Mata Pelajaran IPA Di Sekolah Dasar (Application of Monopoly Game to Improve Students Learning Outcomes on Natural Science Subject in Primary School). From the observation, I found that the students' activeness improved about $11 \%$ from $79 \%$ in cycle I into $90 \%$ in cycle II. The students learning outcomes raised about $22 \%$ from $73 \%$ in cycle I into $90 \%$ in cycle II. The students' responses raised, too, about $8 \%$ from $77 \%$ in cycle I into $85 \%$ in cycle II.

Meanwhile, the followings are the designs of the Monopoly game containing Javanese script. 


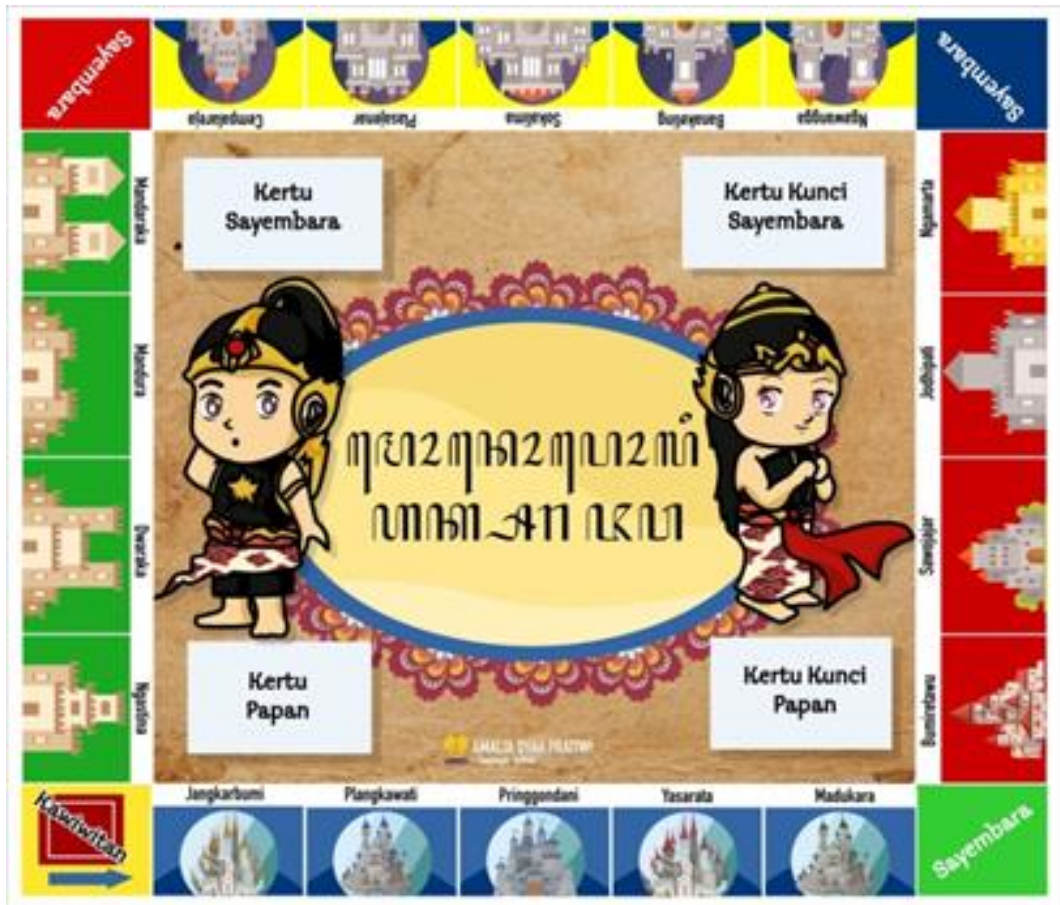

Picture 1 Monopoly board containing Javanese script
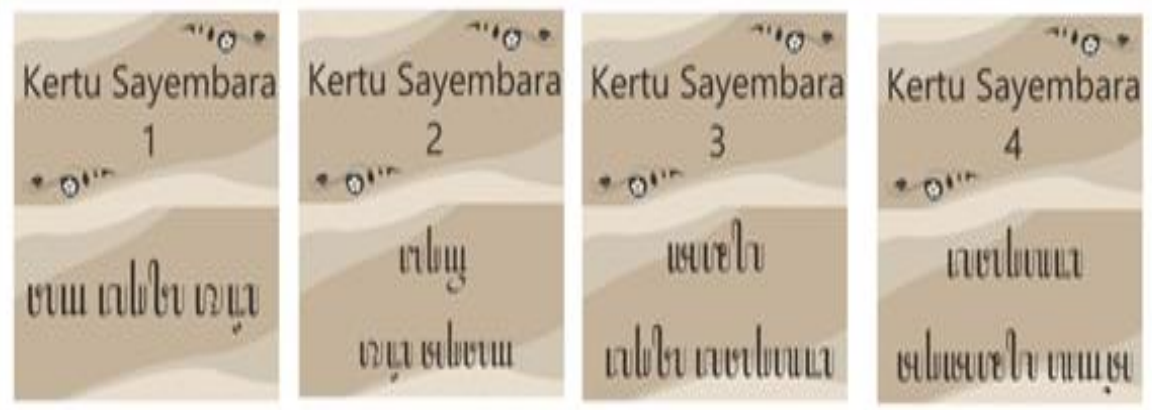

Picture 2 Game Cards
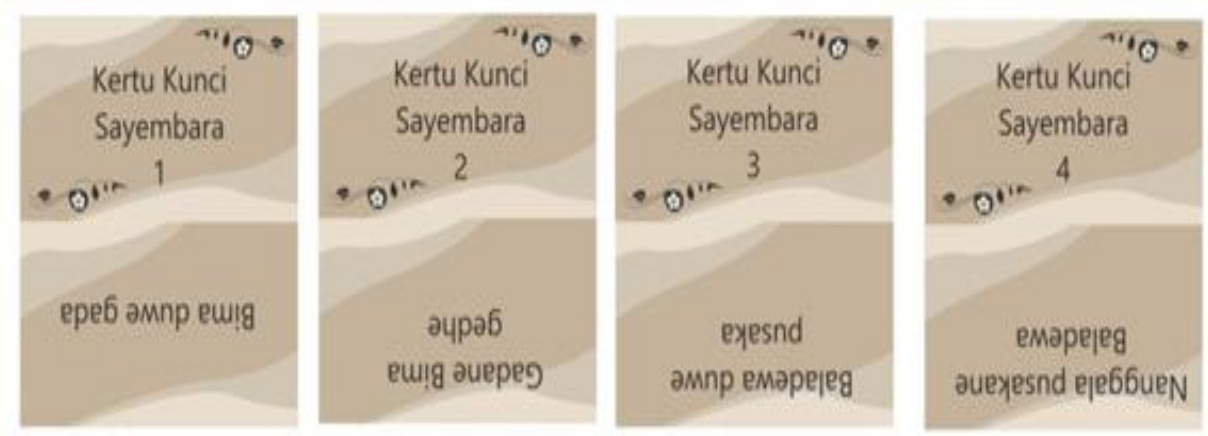

Picture 3 Game Key Cards 


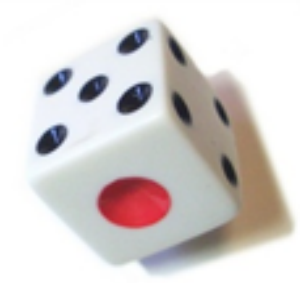

Picture 4 Dice

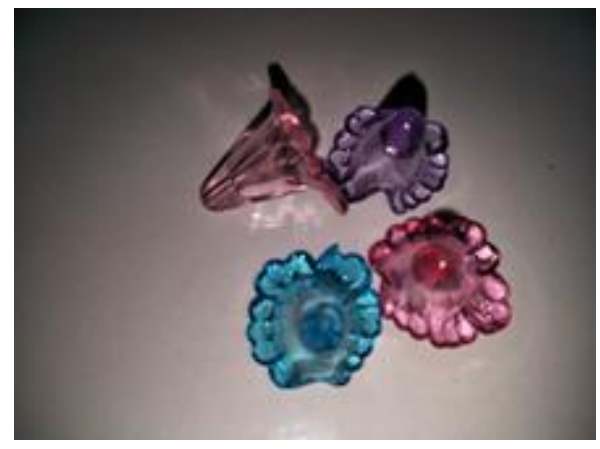

Picture 5 Pawn for Monopoly game containing Javanese script
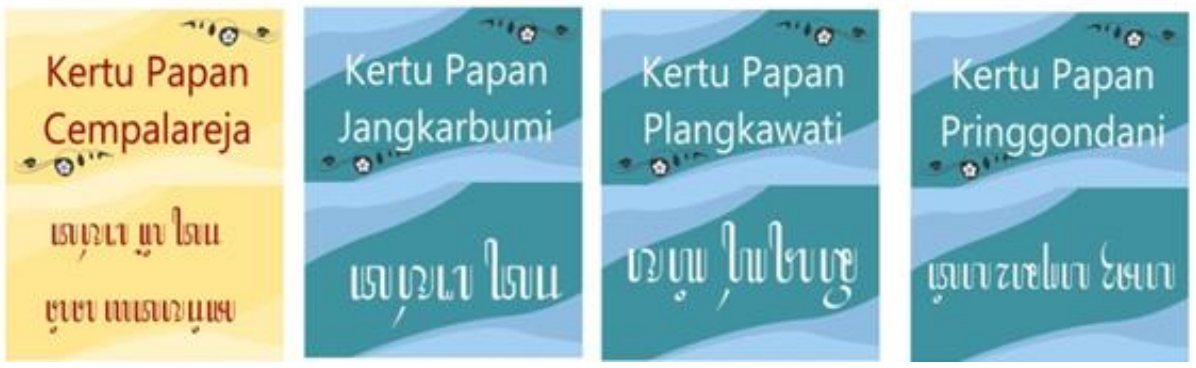

Picture 6 Board Cards
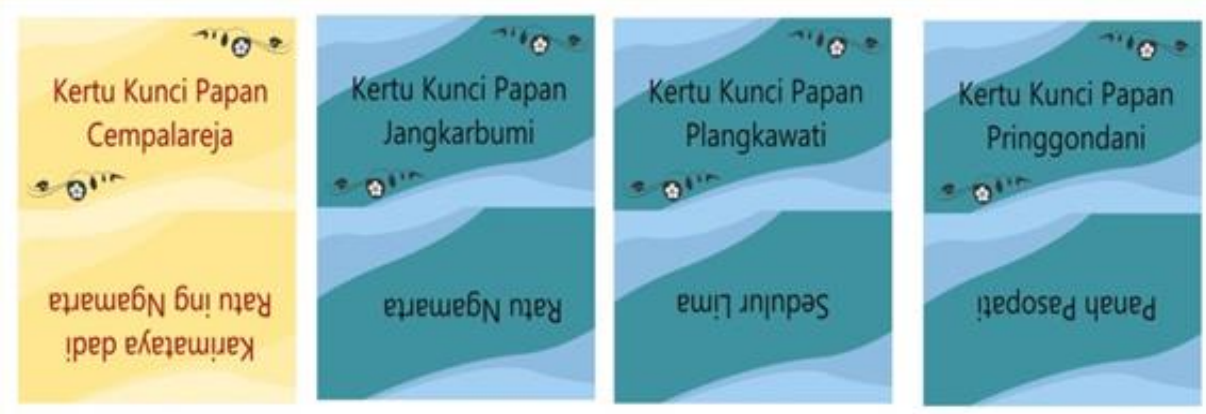

Picture 7 Board Key Cards

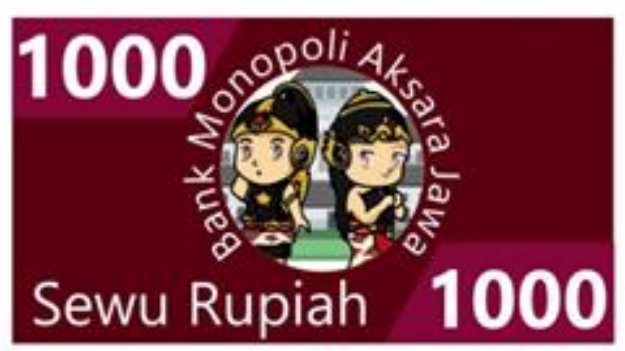




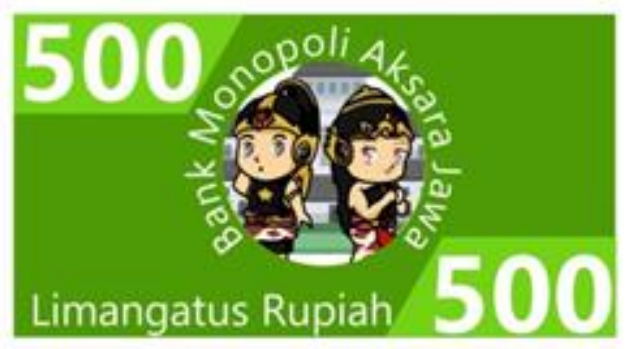

Picture 8 Money Toy

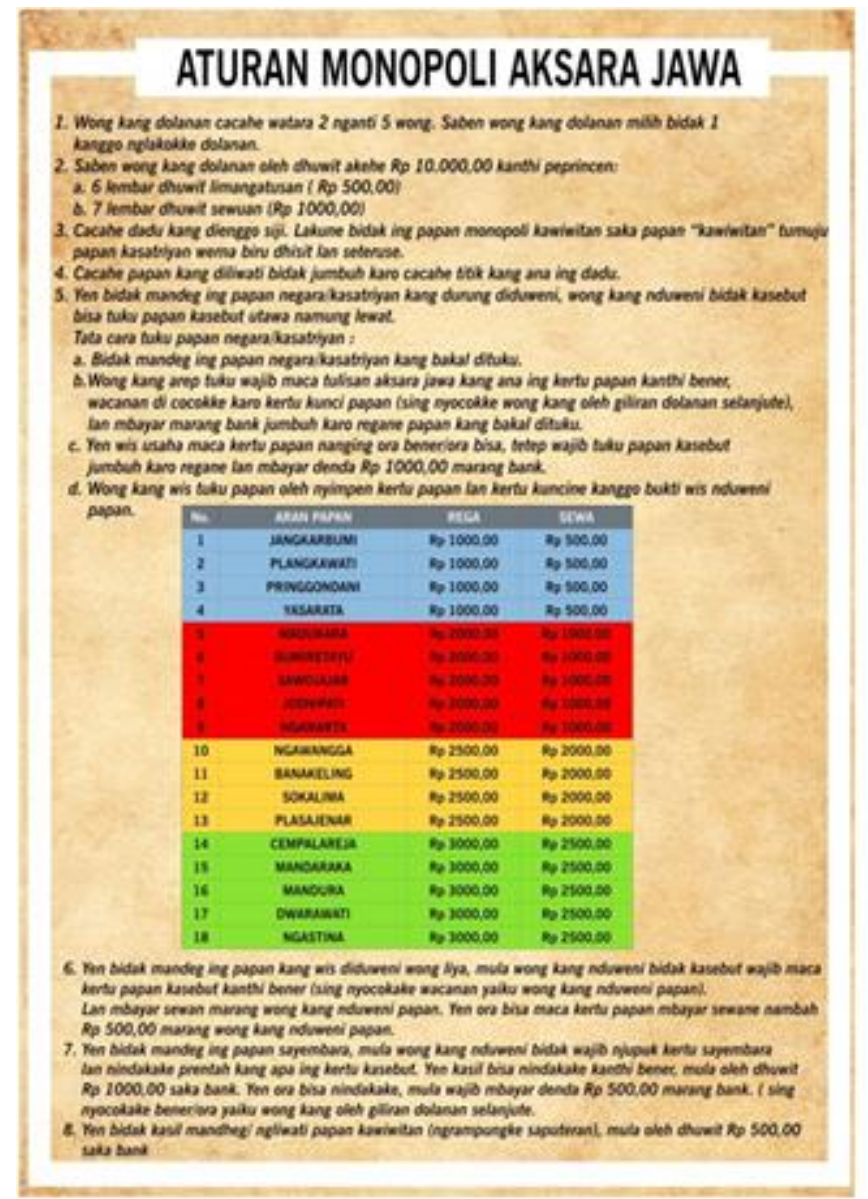

Picture 9 Rule of Game 

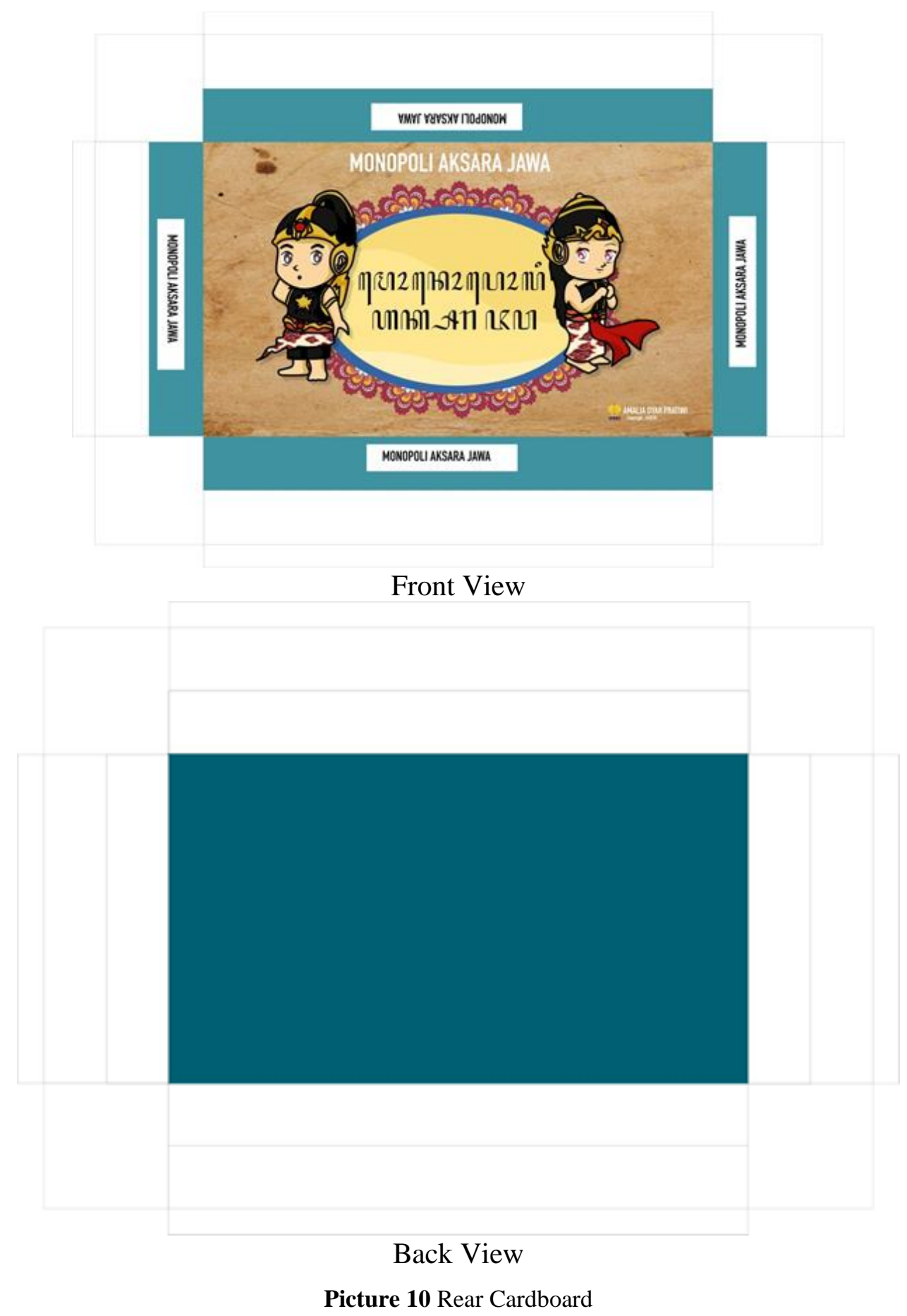

\section{Validation of Assessors' Assessment}

Table 1 Recapitulation of Assessment Validation Components of Content, Presentation, and Linguistic Feasibilities

\begin{tabular}{lccl}
\hline $\begin{array}{l}\text { Validator/ } \\
\text { Assetal Score’ercentage }\end{array}$ & Criteria \\
Media & 98 & $98 \%$ & Excellent \\
Lesson & 44 & $97,8 \%$ & Excellent \\
$\begin{array}{c}\text { Material } \\
\text { Language }\end{array}$ & 33 & $94,3 \%$ & Excellent \\
\hline
\end{tabular}

Table 1 shows that from the assessment of the presentation conducted by the assessors I got score 98 at percentage $98 \%$ and it is included into "excellent" category. From the assessment of the content feasibility conducted by the assessor I got score 44 at percentage $97.8 \%$ and it is included into "excellent" category. While from the assessment of linguistic component conducted by the linguistic assessor, I got score 33 at percentage $94.3 \%$ and it is included into 
"excellent" category. Based on the assessment of validation instrument of each component conducted by media, lesson materials, and linguistic assessors, I can draw a conclusion that monopoly game containing Javanese script in the Javanese learning is significantly applicable.

\section{Questionnaire on Students' and Teacher's Responses}

Monopoly game in Javanese script which has been confirmed as excellently applicable and that has been revised just as suggested by the assessors subsequently was tested in small group. Pictured book as a media was then tested onto 5 grade IV C students of SD Islam Al Madina Semarang. Those students watched the demonstration and applied the monopoly game Javanese script. Then the 5 students were given questionnaires and they were asked to fill in the questionnaires on students' responses to the monopoly game containing Javanese script. The students' responses were then employed to revise the monopoly game before being applied to main product testing.

Based on the responses given by 5 grade IV C students of SD Islam Al Madina Semarang, all 10 aspects got positive responses (yes) so that all aspects got score 5 at percentage $100 \%$. Based on the theoretical study stated by Sadiman (2014:7) media is everything that can be used to deliver message from the sender to the receiver so it will stimulate the students' mind, feelings, attention, interest, as well as enthusiasm so that the learning process lasts.

The questionnaire on teacher's response was given to Javanese teacher of grade IV C of SD Islam Al Madina Semarang to assess the monopoly game containing Javanese script during the Javanese learning. The questionnaire was given after observing and applying the monopoly game to the Javanese learning.

Based on the response given by the classroom teacher of grade IV C of SD Islam Al Madina Semarang, in small-group product testing on monopoly game, all 10 asked aspects got positive response (Yes) at total score 10 or $100 \%$. Percentage $100 \%$ means excellently effective. In addition, the teacher gave comments on the monopoly game, she thought that the learning book was excellent as it eased the students learning the Javanese script through traditional game. The age range of primary students is 7-12. Based on cognitive development theory stated by Piaget, primary students are in the concrete operational stage.

\section{Effectiveness of Monopoly Game Containing Javanese Script}

The effectiveness of the monopoly game was found through students' cognitive learning outcomes improvement. The students' cognitive learning outcomes were found from pretest and posttest scores. The pretest scores were found before the Javanese learning particularly Javanese script lesson using monopoly game as teaching tool began. Posttest score was found after Javanese script lesson for Javanese learning using monopoly game finished. Based on the average pretest score, i.e. 52.72 and average posttest, i.e. 90 the pretest and posttest scores improved about 0.78 . In addition, the amount of the students meeting the learning mastery criteria of the pretest were $4(18.18 \%)$ and 22 students met the mastery learning criteria of the posttest $(100 \%)$.

I conducted normality test on pretest and posttest scores to find the right data analysis method to apply. Based on the calculation using Kolmogorov method, statistical score for pretest was 0,2 and statistical score for posttest was 0.2. The data was confirmed as normally disrtributed if $\mathrm{Sig}>\mathrm{a}$ or $0.2>0.05$. so I can make a conclusion that pretest and posttest scores are distributed normally, so the next calculation used Maka dapat disimpulkan bahwa data nilai pretest dan postest berdistribusi normal, maka perhitungan selanjutnya menggunakan teknik statistik parametrik.

Berdasarkan aspek kajian empiris yang mendukung penelitian ini adalah penelitian Faudany Agustiya, dkk (2017) yang berjudul "Influence of CTL Model by Using Monopoly Game Media to The Students' Motivation and Science Learning Outcome". The research shows that monopoly game was effectively applied to the learning of grade IV students, which was proven by the improving N-Gain about 0.71 . Fengfeng Ke and Barbara Gabonski Vol. 38 (No.2/2007) titled "Game Playing for Math Learning: Cooperative or Not?" explain that learning by playing is more effective than doing exercises. This is in line with the study conducted by Christian Sebastian Loh published in a journal titled "Researching and Developing Serious Games as Interactive Learning Instructions".

The learning outcomes difference between pretest and posttest shows the difference between the learning outcomes before and after the application of monopoly game to Javanese learning. I found that $t_{\text {count }}$ was 11.666 dan $t$ table 
was 2.080 that shows that $t_{\text {count }}>t_{\text {table }}$ then Ha is accepted and Ho is rejected which means that Monopoly Game for Javanese Script is effectively applied to the learning of Javanese subject to improve the students learning outcomes.

Average improvement test of pretest and posttest is presented below. Based on table 2 it was found out that $(N$-gain) data pretest and posttest was 0.78 at average difference 37.28 .
Table 2 (N-gain)

\begin{tabular}{cc}
\hline Category & Value \\
\hline Pretest & 52.72 \\
Posttest & 90 \\
Average difference & 37.28 \\
N-gain & 0.78 \\
Criteria & High \\
\hline
\end{tabular}

The difference between pretest and posttest scores after the application of monopoly game of Javanese script is presented in the line chart below.

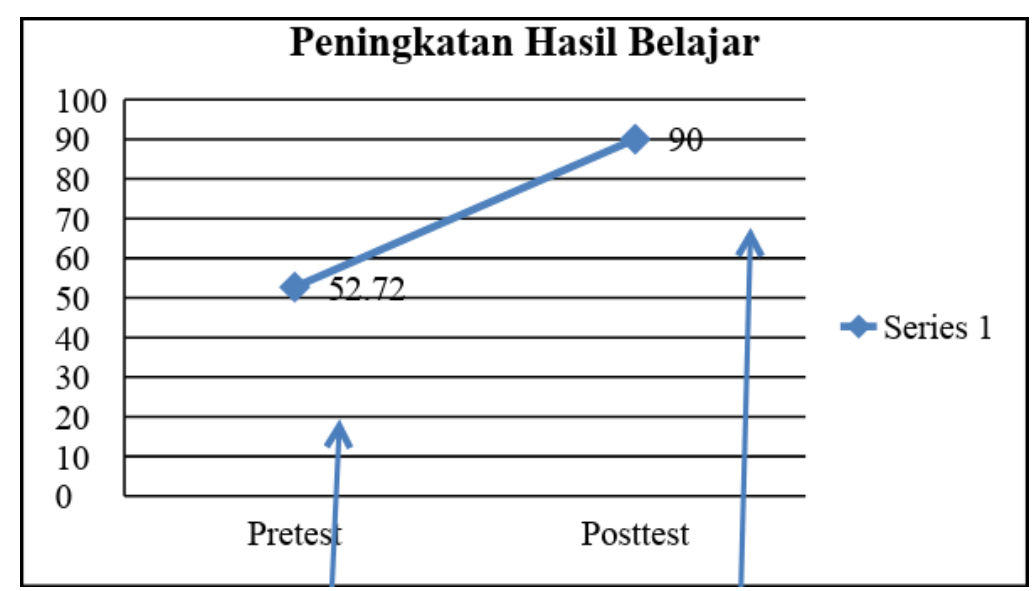

Picture 11 Line Chart of Difference between Pretest and Posttest Scores

The picture above shows the improvement of learning outcomes in pretest and posttest at average difference 37.28. The average improvement shows that monopoly game containing Javanese script was effective to be applied to Javanese learning to grade IV C students of SD Islam Al Madina Semarang.

\section{Conclusion}

From the explanation above, I can draw a conclusion that monopoly game containing Javanese script is effective to be applied to the Javanese learning.

\section{Gratitude}

I would like to thank my two beloved parents, my father, Sujatmiko, and my mother, Solichah as well as my sister Adelia Putri Permatasari for all their prayers and support; my main adviser, Dra. Sumilah, M.Pd. for her advices and suggestions for revisions for this article.

\section{Reference}

Agustiya, Faudany. dkk (2017). "Influence of CTL Model by Using Monopoly Game Media to The Students' Motivation and Science Learning Outcome". Jurnal of Primary Education. Vol 2

Azizah, Nur. 2012. "Penerapan Media Monopoli Untuk Meningkatkan Hasil Belajar Siswa Pada Mata Pelajaran IPA Di Sekolah Dasar.” Jurnal Nasional. Vol 1

Daryanto. 2016. Media Pembelajaran. Yogyakarta: Gava Media.

Ke, Fengfeng and Barbara Gabonski. 2007. "Game Playing for Maths Learning: Cooperative or Not?”.38 (2)

Lin, Chung Hong. 2012. "Game Based Remidial Instuction in Mastery Learning for Upper Primary School Students". Educational Technology \& Society Journal. 16 (2)

Loh, Sebastian Christian. 2009. "Reseacrhing and Developing Serious Games as 
Interactive Learning Instructions" Jurnal Internasional, 1(4)

Pitadjeng, 2006. Pembelajaran Matematika Yang Menyenangkan. Jakarta: Departemen Pendidikan Nasional

Purwanto, dkk. 2012. "Implementasi permainan Monopoli Fisika Sebagai Media Pembelajaran dalam Pembelajaran Kooperatif Tipe TGT untuk Meningkatkan Prestasi Belajar dan Mengetahui Profil Kemampuan Berpikir Kritis Siswa SMP.” Jurnal Pendidikan Fisika FMIPA .17 (1)

Solekhah. 2015. "Pengembangan Media Monopoli Tematik Pada Tema Tempat
Tinggalku Siswa Kelas IV SD N

Babarsari." Jurnal Nasional. 09 (07)

Sugiyono. 2013. Metode Penelitian Pendidikan Pendekatan Kuantitatif. Kualitatif, dan R\&D. Bandung: Alfabeta.

2015. Metode Penelitian Pendidikan. Bandung: Alfabeta.

Susanto, Ahmad. 2013. Teori Belajar Pembelajaran di Sekolah Dasar. Jakarta:Prenadamedia Group.

Syahbrina, Maulia. 2017. "Pengembangan Media MONORAJA (Monopoli Aksara Jawa) untuk Siswa Sekolah Dasar”. 4(3) 